\title{
特別支援
}

わが国の教育心理学的研究は特別支援教育に

どのようなエビデンスを与えているのか

一エビデンス・レベル分類（案）による研究の概括を通して——

\author{
菊 池 哲 平 \\ (熊本大学)
}

\section{Current Status of Evidence Presented in Japanese Educational Psychological Research in Special Needs Education}

\author{
TEPPEI KIKUCHI \\ (KUMAMOTO UNIVERSITY)
}

This paper reports on the evidence-level classification (draft) of Japanese educational psychological research in special needs education. Since 2007, 585 research papers published in academic journals have been classified as being evidence-level based on their research design. Although the largest number of studies have been published on the topics of "Autism Spectrum Disorder (ASD)" and "Developmental Disor der (DD)," the topics of "auditory disorders," "language disorders," and "ADHD" were more advanced from the viewpoint of evidence level. As many studies on "ASD" and "DD" were based on a single case design, it is therefore important to increase the evidence-level by systematically reviewing these studies. Furthermore, many studies on "regular classes" have been published since 2007, and evidence-level was also relatively high. On the other hand, there have been few papers on "classes for special needs children." Taken as whole, it is suggested that educational psychological research provides valuable evidence for special needs education.

Key Words: special needs education, evidence-level, regular classes

本稿は, 2007 年の特別支援教育の開始以降，わが国の教育心理学的研究がどのようなエビデンスを提供 してきたのかについて, エビデンス・レベル分類（案）による概括を行うものである。2007 年以降に学 会誌に掲載された 585 本の研究論文について，研究デザインを基にしたエビデンス・レベル分類を行った。 論文発表数としては「自閉症スペクトラム障害」と「発達障害全般」が多かったものの，「聴覚障害」「言 語障害」「ADHD」のエビデンス・レベルが高かった。「自閉症スペクトラム」及び「発達障害全般」に 関する研究は, シングル・ケース・デザインに基づくものが多いため, これらの研究に対してシステマ ティック・レビューを行うことでエビデンス・レベルを高めていくことが考えられた。さらに 2007 年以 降は「通常の学級」をフィールドとした研究が多く発表されており, エビデンス・レベルも比較的高かっ た。一方，「特別支援学級」をフィールドとした論文は少なく，これからの取り組みが期待される。結果 として, 教育心理学的研究が特別支援教育の有益なエビデンスを提供していることが示唆された。 キーワード：特別支援教育，エビデンス・レベル，通常の学級 


\section{はじめに}

2007 年度より開始された特別支援教育も 10 年の時 を経た。本誌『教育心理学年報』においても，2007 年 度より「障害部門」の名称が「特別支援部門」に変更 され，日本教育心理学会を始めとする諸学会における 特別支援教育分野の研究動向について論考が進められ てきた。

特殊教育から特別支援教育に制度変更されたことに よる最も大きな違いは，とりもなおさず「通常の学級 に在籍する発達障害のある览童生徒への積極的な支援」 が位置づけられたことにある。平成 19 年 4 月 1 日付け で通知された「特別支援教育の推進について (通知)」 (文部科学省, 2007) では, 特別支援教育の理念として 「これまでの特殊教育の対象の障害だけでなく，知的な 遅れのない発達障害も含めて, 特別な支援を必要とす る幼児児童生徒が在籍する全ての学校において実施さ れるものである」と明確に記しており，そのための体 制整備（校長等の責務の明示, 校内委員会の設置, 実態把握, 特 別支援教育コーディネーターの指名, 個別の教育支援計画の策定 と活用など）が求められている。これらの方針に基づき, この 10 年あまり, 幼稚園・小学校・中学校そして高等 学校等における発達障害のある幼児・览童及び生徒へ の支援が現場レベルでは模索されてきた。このような 教育現場の取り組みに対し, 教育心理学を始め学習心 理学, 発達心理学, 臨床心理学といった関連する心理 学分野学界には, その具体的な支援法のバックグラウ ンドとなる知見の提供や, それらの集積に基づく理論 構築が求められていることは言うまでもない。

それでは，実際に教育心理学は特別支援教育にどれ だけの貢献を果たしてきたのだろうか。特別支援教育 の開始に伴い, 発達障害や通常の学級に打ける支援 ニーズが高まってきているが, 教育心理学的な立場か らは，それらのニーズに応えるだけのエビデンスをど れだけ提供しているのだろうか。本稿では，2007 年の 特別支援教育開始以来，今日（2018 年 9 月時点）まで公 刊された各学会誌に掲載された論文について, 障害種 別やフィールド別の集計を行い, 教育心理学が特別支 援教育に与えているエビデンスを整理しつつ論考をし たい。

また, エビデンスの影響を考える際に重要なのは, 単純な論文や発表本数という量的な観点からの動向だ けでなく，それらの論文が持つエビデンス・レベルを 踏まえて影響の強さを検討することである。近年, 医 学や薬学分野に拈いては「エビデンスに基づく医療
(Evidence-based Medicine; EBM)」という概念が叫ばれ, 研 究による成果・知見を集積する際に, その研究デザイ ンによってグレードをつけて評価する, という考え方 が提唱されている。例えば, 日本肝臓学会における肝 癌治療ガイドラインの策定に於いては, 基礎となる文 献リストから以下のエビデンス・レベルに基づいて評 価し, 推奨されるべき治療法の選択が行われている（日 本肝臟学会, 2005)。

レベル 1a：ランダム化比較試験のメタアナリシス

レベル $1 \mathrm{~b}$ : 少なくとも一つのランダム化比較試験

レベル $2 \mathrm{a}$ : ランダム割付を伴わない同時コントロー ルを伴うコホート研究

レベル $2 \mathrm{~b}$ : ランダム割付を伴わない過去のコント ロールを伴うコホート研究

レベル $3:$ ケース・コントロール研究 (後方視的研究)

レベル 4 : 処置前後の比較などの前後比較, 対照群 を伴わない研究

レベル $5:$ 症例報告, ケースシリーズ

レベル 6: 専門家個人の意見 (専門家委員会報告を含む)

こうしたエビデンスレベルの設定は, 特に因果関係 の証明という観点から設定されており, 複数の研究を 階層的に重み付けすることによって, 効率的に治療に 有効な処置・処方を見出していくことを目的にしてい る。特別支援教育分野においても, 効果的な指導法や アプローチの方法を見出していく場合に, 単なるエビ デンスの集積という観点だけでなく, それぞれの研究 デザインに基づいて重み付けを行いながら整理してい く必要があるのではないだろうか。

もちろん, 医学分野に扔けるエビデンス・レベル分 類を心理学分野, 特に特別支援教育分野に適用するこ とには問題がある。例えば医学分野におけるランダム 化比較試験はかなり厳密に群統制を行うが, 障害のあ る人を対象とする場合, 知的水準や障害の状態などに よって幅が広いためターゲットを絞りにくく、どうし てもグループ編成が困難になりやすいため, 群統制も 緩やかな基準で行われることが多い。また医学分野で は盲検化がデフォルトであるが，心理学分野で学校現 場を主なフィールドとする場合, 比較対象となった児 童生徒には介入を行わないことが倫理的問題をはらむ ことになるため, 盲検化は困難である。さらに医学分 野では低いエビデンス・レベルと位置づけられている ケース研究 (症例報告) は特別支援教育ないし臨床心理 学研究では重要な研究方法であると認識されており, 中でもシングル・ケース・デザインに基づいて厳密に 計画された研究はエビデンス・レベルとしては上位に 
Table 1 特別支援教育分野におけるエビデンスレベル 分類 (案)

\begin{tabular}{|c|c|c|}
\hline レベル 1 & & $\begin{array}{l}\text { 対照群を設定した比較統制実験（自然実験デザイ } \\
\text { ンを含む）や前方視的コホート研究 }\end{array}$ \\
\hline \multirow[t]{2}{*}{ レベル 2} & $\mathrm{a}$ & $\begin{array}{l}\text { 対照群を設定しない実験研究（条件比較など）や } \\
\text { 前方視的コーート研究 }\end{array}$ \\
\hline & $\mathrm{b}$ & 大規模標本（対象者 150 名以上）に基づく調查研究 \\
\hline \multirow[t]{2}{*}{ レベル 3} & $\mathrm{a}$ & $\begin{array}{l}\text { シングル・ケース・デザインを用いた前方視的 } \\
\text { ケース研究 }\end{array}$ \\
\hline & $\mathrm{b}$ & 小規模標本 (対象者 150 名未満) に基づく調查研究 \\
\hline \multirow[b]{2}{*}{ レベル 4} & a & 後方視的コホート研究 \\
\hline & $\mathrm{b}$ & $\begin{array}{l}\text { シングル・ケース・デザインを用いていない後方 } \\
\text { 視的ケース研究 }\end{array}$ \\
\hline レベル 5 & & 専門家個人の意見 \\
\hline
\end{tabular}

評価されるべきであろう。わが国においても神山・岩 本・若林（2017）や須藤（2018）において，シングル・ ケース・デザイン研究が持つエビデンス基準について 詳細な検討が行われており，一定レベル以上の基準を 満たしたシングル・ケース・デザインによる研究と, それ以外の後方視的ケース研究を区別することで，工 ビデンス・レベルを高く設定しても良いと思われる。

本稿では, 上述した問題意識を基に, 特別支援教育 (心理分野) におけるエビデンス・レベル分類として, Table 1 のように設定することを提案する。レベル 1 と して, 独立変数と従属変数の関係が最も明確になるラ ンダム化比較試験（RCTs）に基づくデザインと，10 名 以上のコホート (小集団) を対象にした前方視的研究 （対称群を設定）を配置した。この 2 つの研究デザインは 因果関係を明確にしつつ，個人差についても統計的処 理の中で均一化されるため, エビデンス・レベルとし ては最も高いと考えることができよう。前述したよう に，群統制に対する完全なランダム化の手続きについ ては保留として議論を進めたい。

続いてレベル $2 \mathrm{a}$ には対称群を設定しない実験研究 （例えば条件比較など）やコホート研究（対称群設定なし）を 配置した。レベル 1 と同様に，エビデンス・レベルは 高いと考えられるが，対称群を設定していないことか ら, 外的基準による独立変数ではないと考えられるた め，エビデンス・レベルを 1 段階下げた。同じくレベ ル $2 \mathrm{~b}$ には大規模標本に基づく調査研究を設定した。ア ンケートやインタビューによる調査は, 回答者や調査 者の主観が入る可能性があるため, ランダム化比較試 験などと比較するとエビデンス・レベルは低いが, 大 規模標本の場合, 統計的に個人差が修正されていると 考えられるため, ある程度のエビデンス・レベルがあ
ると言っても良いだろう。研究の内容として, 収集し た多数のデー夕を被験者の属性等によってクロス集計 や相関分析を行うため, レベル $2 \mathrm{a} に$ 設定した対称群を 設定しない実験研究などと同レベルであると判断した。 大規模であるかどうかは，150 名以上の対象者を基準 とした。

レベル $3 \mathrm{a}$ にはシングル・ケース・デザインを用いた 前方視的ケース研究を設定した。ベースラインの測定 およびセッションごと又は定期的に従属変数の測定が 行われていることを条件とし, セッション開始前と セッション開始後の比較のみが行われているものは該 当しないものとした。レベル $3 b$ は小規模標本による 調査研究とした。

レベル 4 は後方視的コホート研究およびケース研究 とした。後方視的研究の場合, 研究開始時点において 従属変数が設定されておらず, セッション中のエピ ソードなどが中心に報告される傾向にあるため, 研究 者の主観的なバイアスがかかる可能性があるため，工 ビデンス・レベルは高くないと判断した。また，そも そも効果が見られたケースのみを論文として報告して いる可能性もある。

レベル 5 は, 特にデータに基づかない研究, 例えば 活動の取り組みや海外の制度などを紹介したもの，シ ステマティック・レビューではない文献研究とした。

これらのエビデンス・レベルの設定は, あくまで案 であり，学界にて幅広く議論がなされる必要がある。 そのため，まずは現在までに発表されている特別支援 教育分野の研究論文について, それぞれに用いられて いる研究デザインに基づいて整理することにより，上 記のエビデンス・レベル分類の設定が妥当なものであ るか，検討を行っていきたい。

\section{7 年以降の学会誌掲載論文数の分析}

今回分析の対象とした論文は，特別支援教育が制度 として開始された 2007 年以降に公刊された『教育心理 学研究』『特殊教育学研究』『心理学研究』『発達心理学

Table 2 分析対象とした文献数（2007-2018 年 8 月 まで）

\begin{tabular}{lrccr}
\hline & 原著 & 資料・短報 & 実践研究・実践報告 & 計 \\
\hline 教育心理学研究 & 8 & 1 & 7 & 16 \\
発達心理学研究 & 33 & - & - & 33 \\
心理学研究 & 3 & 6 & - & 9 \\
特殊教育学研究 & 85 & 130 & 114 & 329 \\
LD 研究 & 44 & 63 & 91 & 198 \\
\hline \multicolumn{1}{c}{ 合計 } & 173 & 200 & 212 & 585 \\
\hline
\end{tabular}




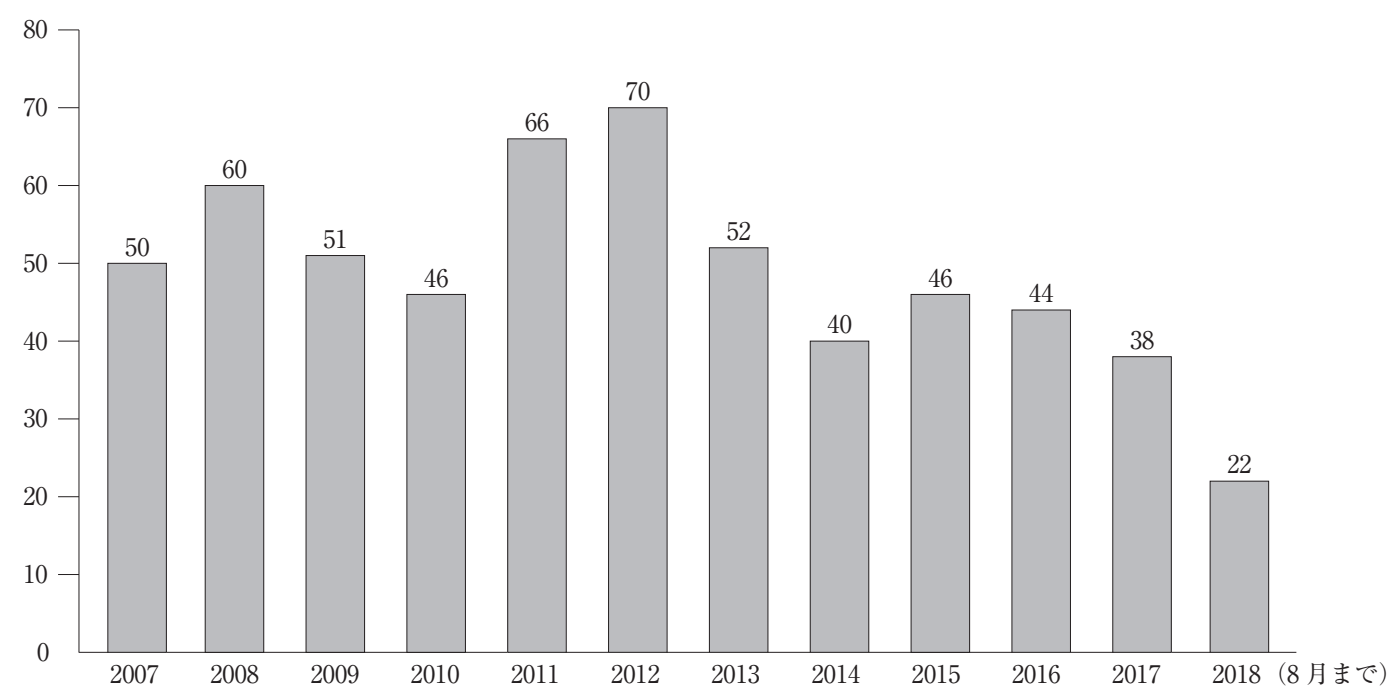

Figure 1 特別支援教育開始（2007）年からの論文数推移

研究』『LD 研究』の 5 誌に揭載された 585 本とした (Table 2)。この 5 誌を取り上げたのは，会員数が 4,000 名以上と多く，一般的にエビデンスの高い論文が掲載 されると認識されているためである。各学会誌により 論文種別が異なるため,「原著」「資料 (短報)」「実践研 究・実践報告」の枠組みに整理し, それ以外の掲載記 事 (「展望・研究動向」「研究時評」や, シンポジウム報告などの 特集記事) は対象としなかった。なお 2018 年度は本稿 執筆時点（2018年 8 月）までの集計である。年次ごとに 集計した論文数を Figure 1 に示した。これをみると 2012 年の 70 本をピークに, その後, 緩やかに減少し ているように思われる。2007一2012 年と 2013-2017 年までの論文数をU 検定にかけたところ， $5 \%$ 水準で 有意であった $(z=2.026, p<.05)$ 。長南（2018）は特別支 援教育に関する学会発表件数が近年減少していること を指摘しており，同様に学会誌揭載論文においても同 様に減少しているものといえよう。長南（2018）は自閉 症スペクトラムに関する研究が減少していることが主 な要因であるとしているが, 学会誌掲載論文では自閉 症スペクトラムに限らず LD や発達障害全般に関する 研究も減少していることが分かる。2012 年が最大值に なることから，執筆や查読に要する期間を踏まえると， 特別支援教育開始直後に実施された研究がこの時期に 多数掲載されているものと推測される。いわばブーム であったと言えるかもしれない。その後, 論文数とし ては 40 本前後で推移しており, 2018 年も 8 月までで 22 本であることから同程度の論文数が見込まれるであ
ろう。

続いて障害種別ごとに論文を整理した。分類の基準 は長南（2018）に倣い，（1）視覚障害，（2）聴覚障害, （3）知的障害，（4）肢体不自由，（5）病弱・身体虚弱, (6) 言語障害, (7) 自閉症スペクトラム障害, (8) ADHD，（9）LD，（10）発達障害全般，（11）重度・重 複障害, (12) その他・障害一般の 12 カテゴリーとし た。この分類は黒住 (2013) や細渕（2014）などでも用 いられており, 障害名やカテゴリー基準の変更に伴い 修正されつつも本誌『教育心理学年報』では伝統的な カテゴリーである。「発達障害全般」については, 対象 や知見の適用範囲が「発達障害」とされているものを, 「その他・障害一般」については, 対象の障害種が特定 されていないものや, 教員研修に関するもの, きょう だい児支援に関するものなどを扱ったものとした。

Figure 2 に障害種別ごとの論文数を示した。発達障 害関連が多数を占めており,「自閉症スペクトラム障 害」「ADHD」「LD」「発達障害全般」で $61 \%$ となった。 本研究の分析対象の中に「LD 研究」が含まれている ためと考えられたため, 念のために「LD 研究」揭載 論文を除外した 389 論文にて同様の集計を行なったが, やはり「自閉症スペクトラム障害」「ADHD」「LD」 「発達障害全般」で $52 \%$ となり過半数を超えた（Figure 3)。 したがって発達障害関連の研究が特別支援教育分野で は大きなウェイトを占めていることが伺える。しかし ながら「ADHD」については, 全論文の $3 \%$ 程度であ り,「LD 研究」に掲載されたものを除くと $1 \%$ 程度の 


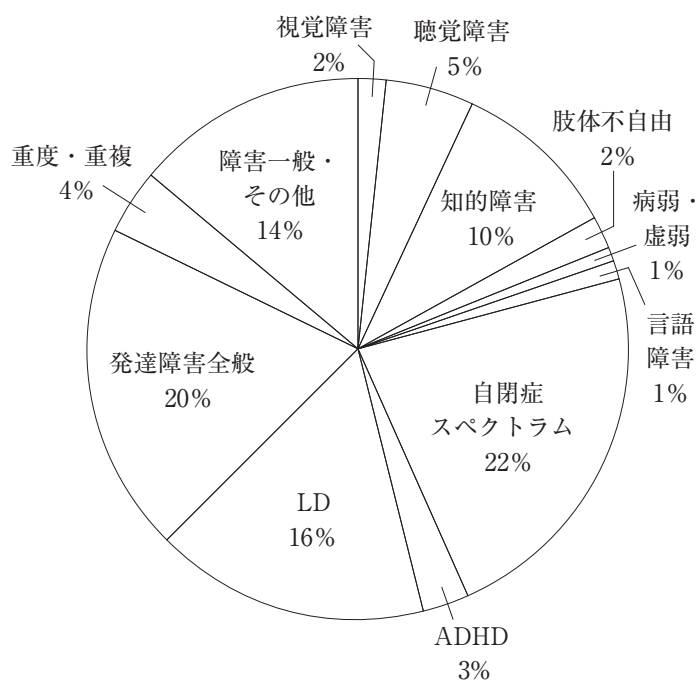

Figure 2 障害領域ごとの論文数の内訳

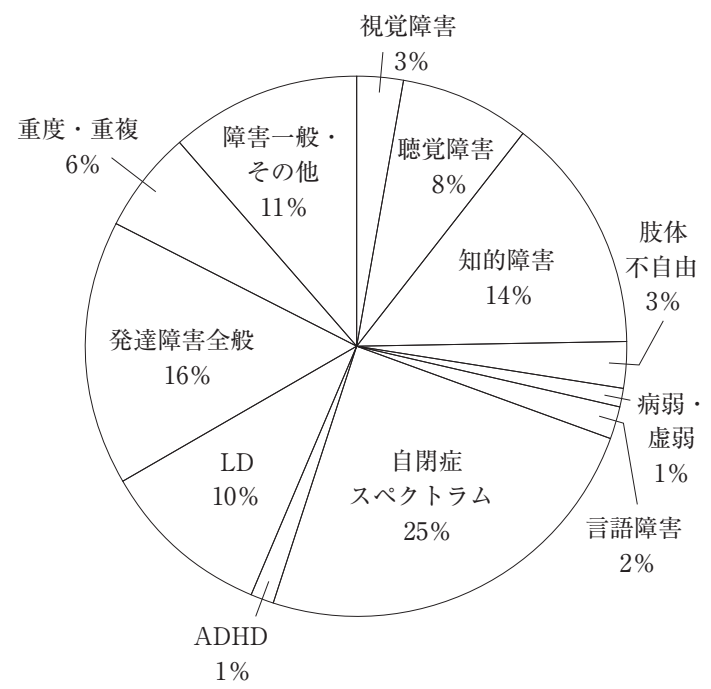

Figure 3 『D 研究』を除いた障害領域ごとの論文数 内訳

本数であった。発達障害関連の中では ADHD に関する 教育心理学的研究が論文数という量的な観点からすれ ば，あまり進んでいないといえる。

その他の障害領域としては，「視覚障害」と「肢体不 自由」が各 $3 \%$, 「言語障害」が $2 \%$, 「病弱・身体虚 弱」が $1 \%$ と論文数が少なかった（Figure 3)。「病弱・ 身体虚弱」と「肢体不自由」は特別支援学校教員免許 状取得にかかる障害領域として設定されているが, こ れらの領域に関しては教育心理学的研究が停滞傾向に
あるといえる。これらの領域についての研究が進んで いくことが望まれる。一方で，「重度・重複障害」につ いては $6 \%$ と比較的多く, 2016 年を除き毎年公刊され ていた。したがって「重度・重複障害」については, 教育心理学的な立場からの研究ニーズがかなり高いと いえよう。

\section{教育フィールドごとの分析}

対象となった論文 585 本について, その研究で得ら れた知見がどのフィールドに貢献するか, 「通常の学 級」「特別支援学級」「特別支援学校」「就学前」「高等 学校」「大学」「クリニック・専門機関」「その他」に分 類して検討した。事例研究では対象となった事例の在 籍学級や学校種で分類し, 論文中に記載がない場合や 実験や調査の場合は，その論文で述べられている知見 が最も貢献する場所に分類した。

また移行支援に関するものは, 研究のスタート時点 である移行元のフィールドに分類した。例えば，赤塚 （2013）では発達障害のある児童の保育所・小学校間の 移行支援について検討されており, 小学校入学後も保 育所での適応に比べて適応しているかどうかを基準に 論じられているため, 就学前の保育所が研究ベースに なっていると判断した。「その他」は, 複数の対象者や 事例が取り上げられている論文で, 通常の学級から支 援学級・支援学校にわたって対象者が募集されている 場合，あるいは，学校ないしクリニックや専門機関で はない場所（福祉施設, 親の会など）が対象となっている 場合である。

分類した結果を Figure 4 に示す。「通常の学級（小． 中学校)」に関するものが最も多く $33 \%$ を占め, その次 に多いのが「その他」の $23 \%$ と「特別支援学校」の

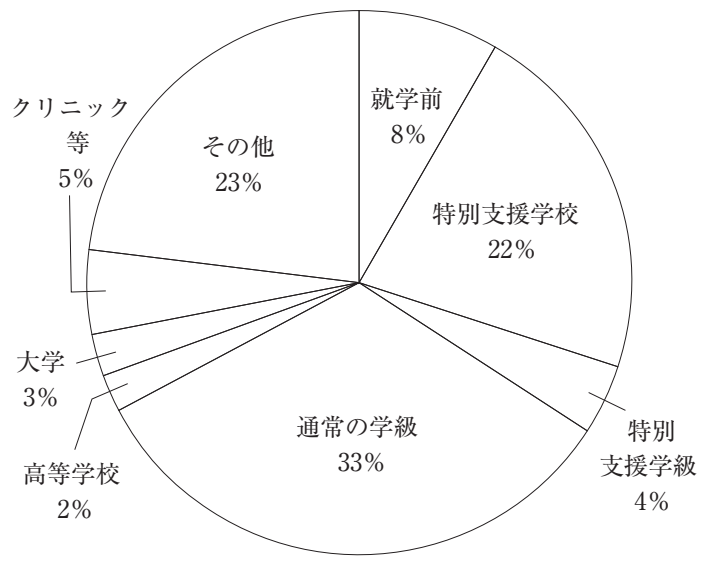

Figure 4 研究のフィールドごとの論文数内訳 
$22 \%$ だった。通常の学級に関するものが最も多いのは, 特別支援教育が開始されたことで通常の学級における 発達障害児への支援に注目が集まっているためと考え られる。また「その他」は，障害特性を明らかにする といったテーマで, 幅広く対象者が募集されているも のが多かった。あるいは保護者支援やきょうだい児に 関するものなど，特定のフィールドに限定されないも のは,「その他」に分類されたため,「その他」のカテ ゴリーが多くなった。

一方，「特別支援学級」は $4 \%$ と少なく，「大学」 (3\%),「高等学校」(2\%) も少なかった。児童生徒学生 の在籍数からすれば, これらのフィールドにおける研 究の割合はかなり低いといわざるをえない。特別支援 学級に関する研究が少ないのは, 特別支援学級担任の 免許保有率が低く（平成 29 年度特別支援教育資料によると 小・中学校で $30.7 \%)$, 研究を推進するための専門的資質 が不足していることが影響しているのかもしれない。 「高校」「大学」に扔ける研究が少ないのも, 同様の実 状からではないかと推測される。今後は，これら特別 支援学級や大学, 高等学校における研究を進渉させる ことが求められるだろう。

特別支援学級における研究の例として, 半田・野呂 （2015）を取り上げたい。この研究は, 小学校における 自閉症・情緒障害特別支援学級担任に対して, ソー シャルスキル指導に関する指導効果の評価について調 查したものである。自閉症・情緒障害は, 特別支援学 校に扔ける主たる障害領域（視覚障害，聴覚障害，知的障害， 肢体不自由, 病弱・身体虚弱, 重複障害）には入って扮らず, そのため特別支援学級にのみ設定されている障害領域 である。さらに実態として自閉症・情緒障害学級では, 自立活動としてソーシャルスキル指導が多く行われて おり，その効果的な取り組みのためにエビデンスを集 積する必要がある。半田・野吕 (2015) では, 指導ニー ズの高いスキルと指導経験のギャップについて調査し ている。指導ニーズとしては「上手にあいさつをする」 「上手に相手の話を聞く」「イライラしたり，ドキドキ したりした気持ちをコントロールする」が高く，指導 経験も比較的多いことが示された。一方で「遊びなど の仲間に入れてもらう」「自分にとっていやなことやで きないことを上手に断る」が指導ニーズは高いものの 指導経験は比較的低く, 他のソーシャルスキルと比べ て指導ニーズと指導経験にギャップがあることを報告 している。これらより自閉症・情緒障害学級担任教員 においては, 指導ニーズと指導経験にギャップが生じ ているスキルの具体的な指導方法についての研修ニー
ズがあることが分かる。半田・野呂（2015）の研究は， 対象者数が 77 名と少なくエビデンス・レベルは $3 \mathrm{~b} に$ 留まるため, 調査対象や地域の拡大など, より高い工 ビデンス・レベルを目指していくことが求められる。 このように特別支援学級における教育実践に貢献する ようなエビデンスを積み重ねることが求められるだろ j。

\section{エビデンス・レベルの分析}

585 本の論文について, Table 1 に示したエビデン ス・レベルの分類基準に基づき分類を行った。その結 果, Table 3 のように「原著」「資料・短報」「実践研 究・報告」間で大きく違いが見られ， $\chi^{2}$ 検定の結果， エビデンス・レベル分類の割合に有意な差が見られた $\left(\chi^{2}(14)=295.48, p<.01\right)$ 。残差分析の結果, 原著論文では レベル 1 論文が多く $(z=6.98, p<.01)$, レベル $3 \mathrm{a}$ が少な かった $(z=-5.95, p<.01)$ 。「資料・短報」ではレベル $2 \mathrm{~b}$ $(z=6.44, p<.01), \quad$ レ゙ル $3 \mathrm{~b}(z=4.53, p<.01), \quad$ レベル 5 $(z=3.17, p<.01)$ が多かった。一方, レベル $3 \mathrm{a}(z=-8.38$, $p<.01)$ とレベル $4 \mathrm{~b}(z=-2.55, p<.05)$ は少なかった。 「実践研究・報告」ではレベル $3 \mathrm{a}(z=13.91, p<.01)$ と レベル $4 \mathrm{~b}(z=3.73, p<.01)$ が多く, レベル $1(z=-6.23$, $p<.01)$, レベル $2 \mathrm{~b}(z=-7.75, p<.01), \quad$ ベル $3 \mathrm{~b}(z=$ $-5.39, p<.01)$ およびレベル $5(z=-2.53, p<.05)$ が少な かった。

このように「原著」論文ではレベル 1 が多いことか ら，エビデンス・レベルとして高い水準にあるものが 発表されていることがうかがえる。その一方で「原著」 論文であっても決してエビデンス・レベルが高くない 論文も存在しており，「原著＝エビデンスが高い」とは 言えないことは留意すべきであろう。その一方,「資 料・短報」ではレベル $2 \mathrm{~b}$ および $3 \mathrm{~b}$ にあたる大規模調 查・小規模調查が多かった。したがって「資料・短報」 ではデー夕数の大きさにかかわらず調査研究が多いこ

Table 3 論文種別ごとのエビデンス・レベルの分類

\begin{tabular}{lrrrr}
\hline & 原著 & 資料・短報 & 実践研究 & 計 \\
\hline レベル 1 & 48 & 24 & 3 & 75 \\
レベル 2a & 19 & 20 & 24 & 63 \\
レベル 2b & 38 & 65 & 4 & 107 \\
レベル 3a & 23 & 17 & 140 & 180 \\
レベル 3b & 28 & 47 & 8 & 83 \\
レベル 4a & 1 & 1 & 4 & 6 \\
レベル 4b & 7 & 5 & 23 & 35 \\
レベル 5 & 9 & 21 & 6 & 36 \\
\hline \multicolumn{1}{c}{ 計 } & 173 & 200 & 212 & 585 \\
\hline
\end{tabular}


とになる。特別支援教育分野では，アンケート調査は 「資料・短報」として投稿されやすいといえよう。

「実践研究・報告」では, シングル・ケース・デザイ ンを用いた論文が突出して多く，またシングル・ケー ス・デザインを用いていない後方視的ケース研究も多 かった。そもそもの論文区分として，「実践研究・報 告」は教育現場での実践を報告するものとして設定さ れており，特別支援教育分野の場合は個々の障害児・ 者に応じた実践がなされることが前提であるため, シ ングル・ケース研究が多いことは，ある意味では必然 的であろう。

続いて，障害種別ごとにエビデンス・レベルの分類 を行った $($ Table 4$)$ 。障害種によっては，該当するエビ デンス・レベルの論文が 1 本も存在しない場合もある ため，エビデンス・レベルに違いがあるかを $\chi^{2}$ 検定な どで比較することができない。そのため, 便宜的にレ ベル 1 を 5 点, レベル 2 を 4 点……換算し, 平均点 を算出した。最もエビデンス・レベル得点が高かった のは「聴覚障害」で 3.97, ついで「言語障害」と $\lceil\mathrm{ADHD}\rfloor$ が 3.71 で同点, 「LD」の 3.65 と続いていた。 得点が低かったのは，「肢体不自由」が 2.55 ,「障害一 般・その他」が2.93, 「病弱・身体虚弱」及び「重 度・重複」が各 3.00 であった。

ここから「聴覚障害」領域ではエビデンス・レベル の高い研究が多く実施されていることが分かる。「聴覚 障害」領域では論文の $32.2 \%$ がレベル 1 のランダム化 比較試験または対称群を設定したコホート研究であり， 研究の方法論としてエビデンス・レベルの高い研究が 定着しているものと考えられる。

また論文本数的には圧倒的に多かった「自閉症スぺ
クトラム障害」と「発達障害全般」は, それぞれ 3.33 と 3.29 となり, 全体の平均とほとんど差がなかった。 これはどちらの領域もレベル $3 \mathrm{a}$ のシングル・ケース・ デザインによるケース研究が多いことによるだろう。 これらの領域のエビデンス・レベルを向上させていく ために，シングル・ケース・デザインによる研究のメ 夕分析などのシステマティック・レビューあるいは小 集団化した形でのコーホート研究が行われることが期 待される。

一方，論文数は少ないものの「言語障害」「ADHD」 領域はどちらも 3.71 と比較的高く, エビデンス・レベ ルの高い研究が行われているようである。また「LD」 領域では，レベル 1 が $20 \%$ と比較的多いだけでなく， 大規模調査研究とシングル・ケース・デザインに基づ いた研究が各 $24.2 \%$ と多数を占めている。 LD はその 発生率が $4.5 \%$ と最も高い障害種であるため大規模調 査がしやすいものと思われる。また学習状況を従属変 数にすることで指導の効果を数值化しやすいという側 面もあるため, RCTs による研究が実施しやすいので はないだろうか。

一方,「肢体不自由」,「病弱・身体虚弱」及び「重 度・重複」領域でエビデンス・レベルが低いのは，ど ちらも障害の状態像が幅広いため, 焦点を絞って対象 児・者を集めることが困難であることが理由ではない かと思われる。例えば脳性まひであったとしても，病 型やまひの状態によって様相は大きく変化する。その ため一つの群として集団を設定することが困難なため, ランダム化比較試験やコホート研究が難しいのではな いだろうか。またケース研究についても, 神山他 (2017) が述べているように，緊急性の高いケースほど

Table 4 障害種別ごとのエビデンス・レベルの分類

\begin{tabular}{|c|c|c|c|c|c|c|c|c|c|c|c|c|c|}
\hline & $\begin{array}{l}\text { 視覚 } \\
\text { 障害 }\end{array}$ & $\begin{array}{l}\text { 聴覚 } \\
\text { 障害 }\end{array}$ & $\begin{array}{l}\text { 知的 } \\
\text { 障害 }\end{array}$ & $\begin{array}{l}\text { 肢体 } \\
\text { 不自由 }\end{array}$ & $\begin{array}{c}\text { 病弱 · } \\
\text { 身体虚弱 }\end{array}$ & $\begin{array}{l}\text { 言語 } \\
\text { 障害 }\end{array}$ & $\begin{array}{l}\text { 自閉症 } \\
\text { スペク } \\
\text { トラム }\end{array}$ & $\mathrm{ADHD}$ & $\mathrm{LD}$ & $\begin{array}{c}\text { 発達障害 } \\
\text { 全般 }\end{array}$ & $\begin{array}{l}\text { 重度· } \\
\text { 重複 }\end{array}$ & $\begin{array}{c}\text { 障害一般· } \\
\text { その他 }\end{array}$ & 計 \\
\hline レベル 1 & 2 & 10 & 8 & 0 & 0 & 1 & 22 & 4 & 19 & 6 & 0 & 3 & 75 \\
\hline レベル 2a & 4 & 9 & 7 & 0 & 0 & 2 & 5 & 3 & 13 & 12 & 2 & 6 & 63 \\
\hline レベル $2 b$ & 1 & 3 & 11 & 3 & 0 & 1 & 9 & 4 & 23 & 27 & 4 & 21 & 107 \\
\hline レベル 3a & 1 & 2 & 18 & 1 & 0 & 1 & 73 & 4 & 23 & 40 & 8 & 9 & 180 \\
\hline レベル 3b & 1 & 5 & 10 & 2 & 5 & 2 & 10 & 0 & 9 & 17 & 3 & 19 & 83 \\
\hline レベル 4a & 0 & 2 & 0 & 0 & 0 & 0 & 2 & 0 & 1 & 1 & 0 & 2 & 6 \\
\hline レベル 4b & 1 & 0 & 1 & 2 & 0 & 0 & 7 & 1 & 5 & 7 & 6 & 3 & 35 \\
\hline レベル 5 & 1 & 0 & 3 & 3 & 0 & 0 & 3 & 1 & 3 & 5 & 0 & 17 & 36 \\
\hline 計 & 11 & 31 & 58 & 11 & 5 & 7 & 131 & 17 & 96 & 115 & 23 & 80 & 585 \\
\hline $\begin{array}{l}\text { エビデンス } \\
\text { レベル平均点 }\end{array}$ & 3.55 & 3.97 & 3.47 & 2.55 & 3.00 & 3.71 & 3.33 & 3.71 & 3.65 & 3.29 & 3.00 & 2.93 & 3.35 \\
\hline
\end{tabular}

注）エビデンス・レベル平均点は, レベル 1 を 5 点, レベル 2 を 4 点, レベル 3 を 3 点, レベル 4 を 2 点, レベル 1 を 1 点と便宜的 に得点化し算出した。 
ベースラインの測定が困難になる，あるいは反転デザ インなどの導入が倫理的に問題になるなどの理由から, シングル・ケース・デザインでの研究実施が困難であ ることも考えられるだろう。いずれにしても，今後は これらの障害領域での研究を増加させつつも, エビデ ンス・レベルを高めるための方策を検討していく必要 があるだろう。

\section{通常の学級での特別支援教育に与えるエビデンス}

続けて，筆者が最も関心のある分野として，通常の 学級における特別支援教育に与えるエビデンスについ て検討をしていきたい。先述した通り 585 本の論文の うち, 通常の学級での取り組みに知見を提供するもの と判断された研究 (対象児が通常の学級に在籍する児童生徒 である, 通常の学級に打いて研究が行われている, など）は 194 本であり，全体の 33\%であった。この 194 本の論文に ついて,さらに障害種別ごとに集計したところ「自閉 症スペクトラム」,「ADHD」,「LD」,「発達障害全般」 のカテゴリーで $84 \%$ を占めており, やはり通常の学級 においては発達障害のある子どもへのアプローチに関 する研究ニーズが高いことがうかがえる。

通常の学級に関する研究のエビデンス・レベルを把 握するため, 障害種別の場合と同じょうに得点化を 行ったところ平均 3.55 となり, 全体のエビデンス・レ ベル平均である 3.35 よりも高かった (Table 5)。これよ り, 通常の学級における特別支援教育の取り組みに対 して, 教育心理学的研究は比較的エビデンス・レベル の高い知見を提供していることが伺える。最も多かっ たのはレベル $3 \mathrm{a}$ の論文で, シングル・ケース・デザイ ンを用いたケース研究であった。続いてレベル $2 \mathrm{~b} の$ 大規模調查が多く、レベル 1 のランダム化比較試験デ ザインの研究も多かった。

近年の通常の学級における研究の中で, エビデン ス・レベルの高かったものを紹介したい。増田・大

Table 5 通常の学級における研究論文のエビデンス・ レベル

\begin{tabular}{crc}
\hline & 本数 & 割合 $(\%)$ \\
\hline レベル 1 & 39 & $20 \%$ \\
レベル 2a & 10 & $5 \%$ \\
レベル 2b & 42 & $22 \%$ \\
レベル 3a & 66 & $34 \%$ \\
レベル 3b & 18 & $9 \%$ \\
レベル 4a & 2 & $1 \%$ \\
レベル 4b & 13 & $7 \%$ \\
レベル 5 & 4 & $2 \%$ \\
\hline 計 & 194 & $100 \%$ \\
\hline
\end{tabular}

山・銘茌・中・小池 (2018) は, 小学校通常学級に在籍 する定型発達児 197 名 ( 1 年生一 6 年生) と LD 児 50 名 (1 年生一 5 年生) を対象に, 音読困難評価における語菓性 判断課題の有効性について検討している。定型発達児 における語彙性判断課題の基準値を基に LD 児の得点 は標準化得点として算出し分析を行っており, さらに LD 児はガイドライン音読課題（稲垣, 2010）に基づいて 読み障害のタイプを分けて分析している。内訳は, 語 彙性判断課題の成績に基づいて, LD 児 50 名を 2 文字 単語課題と 4 文字単語課題共に低成績である 23 名を $\mathrm{A}$ タイプ, 2 文字・4 文字課題共に非低成績だった 14 名 をD タイプとして分類した。さらに 4 文字単語課題の み低成績である 12 名を B夕イプとした。2 文字単語課 題のみ低成績者を C タイプとしたが 1 名のみだったた め分析から除外している。各タイプのガイドライン音 読課題の成績を比較したところ, A タイプは全ての課 題で D タイプよりも平均標準化得点が高く, 音読に全 般的な弱さがあることが窺われた。一方, B タイプの $\mathrm{LD}$ 児は, ガイドライン音読課題においては有意味単 語課題のみ D タイプよりも平均標準化得点が高く, 単 音課題や無意味単語課題では有意差が見られなかった。 したがって短単語や無意味単語の音読には困難を示さ ないが長単語や有意味語には困難を示す児童が一定数 存在し, 語彙性判断課題の 2 文字課題と 4 文字課題の 成績を比較することで，そのような児童を判断できる ことを示唆している。増田他 (2018) の研究では, LD 児の得点を標準化得点に基づいて評価していることか ら, 実質的に LD 児群と定型発達児群を比較している RCTs に基づく研究と判断でき, 高いエビデンスを提 供していると言える。

また高畑（2018）は, 九九学習で誤答率の高い九九の 要因と特異数を明らかにするために, 定型発達児と発 達障害児を比較している。高畑（2018）の研究は研究 1 と研究 2 に分かれており, 研究 1 では通常の学級に在 籍する小学校 2 年生 122 名の各九九の誤答率を調査し, 研究 2 では 23 名の発達障害児 (小学校 2 年生) に対して 研究 1 と同様の調查を行っている。研究 2 の分析では 研究 1 で得られた定型発達児の正答率・誤答率との比 較を行い, 発達障害児の特徴として被乗数が $7,8,9$ と 九九学習後半で学習する数で誤答率が高いこと, 定型 発達児では 1 と 5 が正答率が高い特異数であるが, 発 達障害児では 1 のみが特異数として機能していること を報告している。こちらも研究 1 のみではエビデン ス・レベルは小規模調査となるためレベル $3 \mathrm{~b}$ となる が, 研究 2 でRCTs を行っていることになるため, 論 
文全体のエビデンス・レベルはレベル 1 まで上昇して いる。高畑（2018）から得られる示唆は，以前に行われ たエビデンス・レベルの低い研究データであっても, 新たに収集したデータと比較することでエビデンス・ レベルが向上する場合がある，ということであろう。 その場合, 研究者が同一である場合は問題ないが, 過 去に収集したデータを研究者間で共有するシステムが あることが必要である。わが国においては，こうした 過去の研究データを公的に共有するシステムが確立さ れていないため，どうしても個々の研究が示すエビデ ンスを集積することが困難である。単純な得点や正答 率などは論文に示された基礎的統計量を基に利用する ことができるが，大規模標本に基づく多変量解析など の場合は生データが必要になる。こうしたデータの共 有システムを構築することも, 今後の教育心理学界に おいて検討されるべき事項であろう。もちろん以前の 研究と比較するためには, その条件統制は厳密になさ れる必要があることは言うまでもなく，そのために必 要な研究手続きについての記載に関する基準も整備さ れる必要があるだろう。

\section{8 年度日本教育心理学会（第 60 回総会, 於 : 慶應義塾 大学）における研究発表の動向}

さて本稿は, 日本教育心理学会総会の記録という意 味合いもあるため, 今年度開催された第 60 回大会にて 発表された特別支援教育関連の研究についても，同様 にエビデンス・レベルからの分析を行いたい。第 60 回 大会では 39 本の特別支援教育に関する研究が発表され た (Table 6)。これは全 580 本中 $6.7 \%$ に当たる。これ までの日本教育心理学会総会における研究発表に占め る特別支援教育分野の割合の経年変化を見ると，特別 支援教育の開始後の大塚（2008）では5.5\%，別府

Table 62018 年度日本教育心理学会総会研究発表本数

\begin{tabular}{lrl}
\hline 視覚障害 & 2 \\
聴覚障害 & 2 \\
知的障害 & 3 \\
肢体不自由 & 1 \\
病弱・虚弱 & 1 \\
言語障害 & 0 \\
自閉症スペクトラム & 3 \\
ADHD & 1 \\
LD & 5 \\
発達障害全般 & 15 \\
重度・重複 & 2 \\
障害一般・その他 & 4 \\
\hline \multicolumn{1}{c}{ 計 } & 39 \\
\hline
\end{tabular}

Table 7 日本教育心理学会第 60 回総会にて発表され た研究のエビデンス・レベル

\begin{tabular}{cc}
\hline & 発表論文 \\
\hline レベル 1 & 3 \\
レベル 2a & 5 \\
レベル 2b & 8 \\
レベル 3a & 1 \\
レベル 3b & 11 \\
レベル 4a & 0 \\
レベル 4b & 5 \\
レベル 5 & 6 \\
\hline 計 & 39 \\
\hline エビデンス・レベル平均点 & 3.05 \\
\hline
\end{tabular}

（2009）は 7.7\%，谷口（2011）は 9.3\%と上昇していた が，黒住（2013）では 7.5\%, 細㴊（2014）は 4.5\%, 長 南（2018）は 4.4\%と減少する傾向にあった。今回, 若 干ながら増加の傾向が見られたのは，どのような要因 によるのかは不明だが，特別支援教育に関する研究が 盛り上がるためには, ある程度の学会発表数が存在す ることが望ましいため, 減少傾向に歯止めがかかった とすれば喜ばしいことではないだろうか。

学会発表論文のエビデンス・レベルを確認したとこ ろ，最も多かったのはレベル $3 \mathrm{~b}$ の小規模調査 $(n=150$ 未満), 続いてレベル $2 \mathrm{~b}$ の大規模調查 $(n=150$ 以上) に 基づくものであった（Table 7)。学会誌掲載論文と異な る点として, レベル 3aのシングル・ケース・デザイン に基づくケース研究が 1 本のみと少ない傾向にあった。 これは日本教育心理学会という特性が影響しているも のと見られる。一方，レベル 5 というエビデンス・レ ベルが低い論文も 39 本中 6 本みられ $15 \%$ を占めてい た。学会誌掲載論文でレベル 5 の論文が示す割合が 6\%であったことを鑑みると, 学会発表研究ではエビデ ンス・レベルの低い論文も比較的多いということにな る。またエビデンス・レベルの平均点は 3.05 点であり, 学会誌揭載論文の平均 3.35 点よりもかなり低かった。 日本教育心理学会では総会での研究発表は査読を経な いシステムであるため，エビデンス・レベルが低いも のでも発表可能ということが影響しているのかもしれ ない。

レベル 5 の研究発表の多くは, 実証的データを収集 する前段階の構想発表ないしは学校現場の実践に関す るデー夕を伴わない報告であった。したがって「エビ デンス・レベルが低い＝価值が低い」と捉えるのでは なく, 今後の研究の起点となるようなアイデアを生み 出す可能性を秘めたものとして, これらの研究発表の 
潜在的な価值を引き出していくことが必要である。そ のように考えると, むしろ学会発表においては, 今回 提案したエビデンス・レベル分類による評価だけでは なく, 研究の多様性を担保するための別角度からのア プローチが必要なのではないだろうか。

\section{おわりに}

本稿では特別支援教育領域における教育心理学的研 究の動向を, エビデンス・レベルという観点から概括 してきた。そのため, 本誌『教育心理学年報』におい て長年踏襲されてきたスタイルとは異なる論展開に なったが, 今後の科学的研究としてのエビデンス・レ ベルの向上という課題に向き合うためには, 個々の論 文の持つエビデンスをどのように評価するかについて， 具体論を避けることはできないと考える。特に特別支 援教育領域においては，医学分野との親和性から，高 いレベルのエビデンス提供が求められよう。今後, 教 育心理学が特別支援教育にどれだけの質の高いエビデ ンスを提供することが可能か, 学界全体で議論しなが ら, より科学的妥当性の高い研究を進めていくことが 求められる。

\section{引用文献}

メ夕分析に用いた文献のうち, 本文で引用していな い論文はオンライン補足資料として掲載した。

赤塚正一 (2013). 通常の学級に在籍する発達障害のあ る児童の保育所・小学校間の移行支援に関する実践 的研究 特殊教育学研究, 51, 311-319.

別府哲 (2009). 特別支援教育に関する教育心理学的 研究の動向と展望一自閉症児者の感情に関する研 究を中心に 教育心理学年報, 48, 143-152. doi:10. 5926/arepj1962.48.0_143

長南浩人 (2018). わが国の特別支援教育における教 育心理学的な研究動向と展望一聴覚障害児教育に焦 点をあてて 教育心理学年報, 57, 112-122. doi:10. 5926/arepj.57.112

半田 健 ·野吕文行 (2015). 小学校における自閉症・ 情緒障害特別支援学級担任を対象としたソーシャル スキル指導に関する調査一A県内 3 市を対象とした
調查から LD 研究, 24, 120-132.

細㴊富夫 (2014). 特別支援教育における教育心理学 的な研究動向と課題一重度・重複障害児の教育実践 研究を中心に 教育心理学年報, 53, 96-107. doi:10. 5926/arepj.53.96

稲垣真澄 (2010). 特異的発達障害診断治療のためのガ イドライン一わかりやすい診断手順と支援の実際 診断と治療社

神山 努・岩本佳世・若林上総 (2017). わが国の障害 児者を対象とした一事例実験デザイン研究における 「エビデンス基準を満たす実験デザイン規準」からの 分析 特殊教育学研究, 55, 15-24.

黒住早紀子 (2013). 特別支援教育に関する教育心理学 的な研究動向と展望一生態学的な視点から 教育心 理学年報, 52, 90-104. doi:10.5926/arepj.52.90

増田純子 - 大山帆子 - 銘苅実土 - 中 知華穂 - 小池敏英 (2018).ひらがな単語の語彙性判断課題による読み 障害览の音読困難の評価一 2 文字単語課題と 4 文字 単語課題に基づく検討 LD 研究, 27, 340-353.

文部科学省 (2007). 特別支援教育の推進について（通 知）Retrieved from http://www.mext.go.jp/b_menu/ hakusho/nc/07050101.htm（2018 年 11 月 10 日）

日本肝臓学会 (2005). 肝癌診療ガイドライン一エビデ ンスレベル Retrieved from https://www.jsh.or.jp/ liver/level\%20classification.htm（2018 年 11 月 10 日） 大塚 玲 (2008). 特別支援教育に関する教育心理学的 研究の動向と展望一知的な遅れのない発達障害児に 関する研究を中心に 教育心理学年報, 47, 127-136. doi:10.5926/arepj1962.47.0_127

須藤邦彦 (2018). わが国の自閉症スペクトラム障害に おける応用行動分析学をべースにした実践研究の展 望一 2012 年から 2017 年 教育心理学年報, 57, 171178. doi:10.5926/arepj.57.171

高畑英樹 (2018). 九九学習で誤答率の高い九九の要因 と特異数一通常の学級の児童と発達障害児の九九学 習結果より LD 研究, 27, 354-364.

谷口明子 (2011). 特別支援教育に関する教育心理学研 究の動向と展望一病弱教育に関する研究を中心に 教育心理学年報, 50, 145-154. doi:10.5926/arepj.50. 145 